\title{
Human small intestinal organotypic culture model for drug permeation, inflammation, and toxicity assays
}

\author{
Jan Markus ${ }^{1} \cdot$ Tim Landry $^{2} \cdot$ Zachary Stevens $^{2} \cdot$ Hailey Scott ${ }^{2} \cdot$ Pierre Llanos $^{2} \cdot$ Michelle Debatis $^{2}$. \\ Alexander Armento ${ }^{2} \cdot$ Mitchell Klausner $^{2} \cdot$ Seyoum Ayehunie $^{2}$
}

Received: 3 July 2020 / Accepted: 23 October 2020 / Published online: 25 November 2020 / Editor: Tetsuji Okamoto

(C) The Society for In Vitro Biology 2020

\begin{abstract}
The gastrointestinal tract (GIT), in particular, the small intestine, plays a significant role in food digestion, fluid and electrolyte transport, drug absorption and metabolism, and nutrient uptake. As the longest portion of the GIT, the small intestine also plays a vital role in protecting the host against pathogenic or opportunistic microbial invasion. However, establishing polarized intestinal tissue models in vitro that reflect the architecture and physiology of the gut has been a challenge for decades and the lack of translational models that predict human responses has impeded research in the drug absorption, metabolism, and drug-induced gastrointestinal toxicity space. Often, animals fail to recapitulate human physiology and do not predict human outcomes. Also, certain human pathogens are species specific and do not infect other hosts. Concerns such as variability of results, a low throughput format, and ethical considerations further complicate the use of animals for predicting the safety and efficacy xenobiotics in humans. These limitations necessitate the development of in vitro $3 \mathrm{D}$ human intestinal tissue models that recapitulate in vivo-like microenvironment and provide more physiologically relevant cellular responses so that they can better predict the safety and efficacy of pharmaceuticals and toxicants. Over the past decade, much progress has been made in the development of in vitro intestinal models (organoids and 3D-organotypic tissues) using either inducible pluripotent or adult stem cells. Among the models, the MatTek's intestinal tissue model (EpiIntestinal ${ }^{\mathrm{TM}}$ Ashland, MA) has been used extensively by the pharmaceutical industry to study drug permeation, metabolism, drug-induced GI toxicity, pathogen infections, inflammation, wound healing, and as a predictive model for a clinical adverse outcome (diarrhea) to pharmaceutical drugs. In this paper, our review will focus on the potential of in vitro small intestinal tissues as preclinical research tool and as alternative to the use of animals.
\end{abstract}

Keywords Intestinal tissuemodel · Drug absorption · Metabolism · Drug-induced toxicity · Nanotoxicity · Inflammation · Wound healing

\section{Introduction}

The gastrointestinal tract (GIT) represents one of the largest body surfaces. It is exposed to food, fluid, medicaments, and toxicants and is an important gateway tissue that plays a crucial role in drug absorption and metabolism, food digestion, and nutrient uptake. Epithelial cells of the small intestine are

Seyoum Ayehunie

sayehunie@mattek.com

In Vitro Life Science Laboratories, Bratislava, Slovak Republic

2 MatTek Corporation, Ashland, MA, USA organized into structures called crypts of Lieberkuhn and finger-like protrusions called villi (van der Flier and Clevers 2009). The crypts harbor Paneth cells (Sato et al. 2009, Gassler 2017) and LGR5+ (leucine-rich-repeat-containing G protein-coupled receptor 5, also known as Gpr49) stem cells (Barker et al. 2007), and the LGR5+ stem cells give rise to transiently amplifying cells of the villi (Mahe et al. 2017). The villi consist of absorptive enterocytes and mucus-producing goblet cells (Bland et al. 1995). Sawant-Basak et al. 2018), hormone producing enteroendocrine cells (Gribble and Reimann 2019), microbial antigen shuttling M-cells (Corr et al. 2008), and chemosensor tuft cells (Ting and von Moltke 2019). The GIT is also one of the major entryways for many human pathogens and thereby plays an important role in microbial recognition and antimicrobial defense. In 
fact, dysfunction of the barrier of the intestinal epithelium is a hallmark of intestinal inflammatory diseases (König et al. 2016). This functional diversity is backed by the complex segmentation, structure, and cellular phenotypes that are present in the gastrointestinal tract.

Historically, a variety of animal models have been used for the preclinical safety evaluation of drugs, intestinal injury, infection, and inflammation as summarized by others (Waterston et al. 2002; Lin and Hackam 2011; Jiminez et al. 2015). Currently, two animal species such as a rodent and a non-rodent (e.g., rats and dogs) are used for short-term (up to 1-mo duration) preclinical safety evaluation of biotechnologyderived pharmaceuticals. If the toxicity profile in the two species is comparable in the short term, the use of only one species for subsequent long-term toxicity studies can be acceptable following regulatory guidelines (https://www.fda.gov/ media/72028/download; https://www.ema.europa.eu/en/ichs6-r1-preclinical-safety-evaluation-biotechnology-derivedpharmaceuticals). Rodents are widely used to study human diseases because of their relatively low maintenance requirements, their rapid reproduction rates, and the availability of resources such as antibodies (Gonzalez et al. 2016). However, rodent models frequently fail to fully mimic clinical signs of human diseases and inflammatory responses (Pizarro et al. 2011). Due to similarities in the anatomical structure of the gastrointestinal tract to that of the human intestine, pigs have been used for intestinal injury, inflammation, inflammatory bowel disease (IBD) modeling, and druginduced gastrointestinal toxicity studies (Walters et al. 2012). Even though pigs and non-human primates provide valuable data on intestinal inflammation and disease conditions, their use for routine intestinal studies is limited due to the high cost associated with their care, potential hazards of carrying highly virulent zoonotic agents, and ethical considerations (Ideland 2009; Coors et al. 2010). Additionally, animal models are low throughput and they do not adequately recapitulate human physiology (Mathur et al. 2017). Therefore, pharmaceutical and academic researchers recognize the need for 3D human intestinal tissue models for preclinical studies since such models are less time-consuming, more cost-effective, and adaptable to high throughput screening (HTS). As reviewed below, these models can be physiologically relevant predictors of human responses including drug absorption and metabolism, drug-induced GI toxicity, inflammation, disease, and intestinal restitution.

\section{Structure and Cellular Phenotypes of Small Intestinal} Epithelium The small intestine constitutes a complex organ system due to its rapid self-renewal time (5-7 d), cellular composition, numerous functions, and the unique dynamic nature of the villi. Functionally, the small intestine is important since $\sim 90 \%$ of the absorption in the digestive tract occurs in this organ (Balimane and Chong 2005). Anatomically, it is divided into three segments, the duodenum, jejunum, and ileum. It is the longest part of the alimentary canal, approximately $3 \mathrm{~m} \mathrm{(10} \mathrm{ft)} \mathrm{in} \mathrm{length,} \mathrm{and} \mathrm{it} \mathrm{has} \mathrm{a} \mathrm{smaller} \mathrm{diameter} \mathrm{(}$ $2.5 \mathrm{~cm}$ ) compared with the large intestine (https:// opentextbc.ca/anatomyandphysiology/chapter/23-5-thesmall-and-large-intestines/). The epithelium of the small intestine differentiates to form finger-like structures on its apical surface to form the villi (Mahe et al. 2017) which are $\sim 0$. $5 \mu \mathrm{m}$ tall. Each villus has hair-like projections called microvilli that pack together to form the brush border. The villi and microvilli increase the intestinal surface area to enhance absorption by 30-600-fold (Kiela and Ghishan 2016), and they play a significant role in nutrient, fluid, drug uptake, solute transport, and host defense (Crawley et al. 2014). At least 22 enzymes and 19 drug transporters are localized in the brush border of the small intestine (Holmes and Lobley 1988). In addition to the villi, the small intestine is organized into folded structures, Kerckring folds, that triple the surface area for rapid intestinal absorption. These folds also slow down the flow of chyme in the gut (Igam et al. 2019).

Within the small intestine, different cell types co-exist in a 3-dimensional space (summarized in Table 1) in which they exchange biochemical and mechanical cues (cellular "crosstalk") that help determine tissue properties such as tissue differentiation and barrier function. The ability of tissue models to mimic such spatial organization and recapitulate the aforementioned interactions makes them more physiological and imparts functionality resembling the in vivo counterparts.

Cell Line-Based Models Caco-2 Cells: Since the 1970s, the Caco-2 cell-based assays are considered as a model for enterocytes (Fogh et al. 1977; Grasset et al. 1984; Rousset et al. 1985) and have been used as the gold standard for drug absorption studies, even though the cells originated from a colon carcinoma. Caco-2 cells have been used alone, or in combination with other cell types such as methotrexatetreated HT29 colon adenocarcinoma cells, as an in vitro model of the small intestine to investigate drug absorption, inflammation, nutrient uptake, and toxicity in the gut (Walter et al. 1996; Hilgendorf et al. 2000, and Kleiveland 2015)) and have been used for drug absorption, distribution, metabolism, and excretion (ADME) studies (Sun et al. 2008). However, the Caco-2 cells form a non-physiological barrier due to paracellular junctions that are much tighter and less permeable, rendering the Caco-2 cultures more similar to the colon than to the human small intestine (Srinivasan et al. 2015). Depending on the laboratory, the clonal type, and passage differences the transepithelial electrical resistance (TEER) values for the Caco-2 cultures varies from 300 to $2400 \Omega \mathrm{cm}^{2}$, compared with TEER values of $12-120 \Omega \mathrm{cm}^{2}$ for human small intestine tissue (Briske-Anderson et al. 1997; Gupta et al. 2013; Takenaka et al. 2014) and $100 \Omega \mathrm{cm}^{2}$ reported for intestinal explants (Artursson et al. 1993). These 
Table 1. Cellular phenotypes of the small intestine epithelium

\begin{tabular}{|c|c|c|c|}
\hline $\begin{array}{l}\text { Cellular } \\
\text { phenotypes }\end{array}$ & Function & Marker/stain & Reference \\
\hline Enterocytes & $\begin{array}{l}\text { Most common cell type in the surface epithelium, } \\
\text { responsible for digestion and absorption of nutrients, } \\
\text { forms the intestinal barrier. }\end{array}$ & Villin, alkaline phosphatase & $\begin{array}{l}\text { Sawant-Basak et al. } \\
\quad \text { (2018) }\end{array}$ \\
\hline Goblet cells & $\begin{array}{l}\text { Secrete mucus which entraps bacteria and prevents their } \\
\text { translocation into the intestinal epithelium. }\end{array}$ & Periodic acid-Schiff (PAS) and MUC-2 & $\begin{array}{l}\text { Sawant-Basak et al. } \\
\quad \text { (2018) }\end{array}$ \\
\hline Paneth cells & $\begin{array}{l}\text { Contribute to crypt morphogenesis and intestinal } \\
\text { homeostasis, the intestinal microbiome (by secreting } \\
\text { antimicrobial peptides such as defensins), and crypt } \\
\text { fission. Associated with intestinal diseases including } \\
\text { ileal Crohn's disease. Originate from intestinal stem } \\
\text { cells. Found at the bottom of small intestine crypts. }\end{array}$ & Lysozyme & $\begin{array}{l}\text { Sato et al. (2009); } \\
\quad \text { Gassler (2017) }\end{array}$ \\
\hline $\begin{array}{l}\text { Enteroendocrine } \\
\text { cells }\end{array}$ & $\begin{array}{l}\text { Produce a range of hormones for chemo-sensing that } \\
\text { have key roles in food absorption, insulin secretion, } \\
\text { and appetite. Scattered along the length of the intesti- } \\
\text { nal epithelium. }\end{array}$ & Anti-synaptophysin & $\begin{array}{l}\text { Gribble and } \\
\quad \text { Reimann (2019) }\end{array}$ \\
\hline Tuft cells & $\begin{array}{l}\text { Play chemo-sensor role, communicate with neurons, } \\
\text { police entry of parasites. Help eliminate gut pathogens } \\
\text { by releasing interleukin-25 (IL-25), which stimulates } \\
\text { mucus-producing goblet cells, recruits immune cells, } \\
\text { and leads to muscle contractions. }\end{array}$ & DCLK1 & $\begin{array}{l}\text { Ting and von Moltke } \\
\text { (2019) }\end{array}$ \\
\hline M-cells & $\begin{array}{l}\text { Highly specialized to take up intestinal microbial } \\
\text { antigens and deliver them to gut-associated lymphoid } \\
\text { tissue (GALT) for efficient mucosal and systemic } \\
\text { immune responses. Subset of intestinal epithelial cells } \\
\text { with reduced brush border and lack of enzymatic ac- } \\
\text { tivity. }\end{array}$ & $\begin{array}{l}\text { Lack of alkaline phosphatase staining; } \\
\text { Transmission electron microscopic observation } \\
\text { of apical epithelial cells that lack brush border }\end{array}$ & Corr et al. (2008) \\
\hline $\begin{array}{l}\text { Lgr5 }(+) \text { stem } \\
\quad \text { cells }\end{array}$ & $\begin{array}{l}\text { Proliferative stem cells located at base of intestinal } \\
\text { crypts, which give rise to TA cells and Paneth cells }\end{array}$ & $\begin{array}{l}\text { Rabbit/mouse Anti-LGR5 antibody; Lgr5 expres- } \\
\text { sion reporters (Lgr5-GFP)/lineage tracing }\end{array}$ & $\begin{array}{l}\text { Barker et al. (2007); } \\
\quad \text { Sato et al. (2009); } \\
\text { Dame et al. (2018) }\end{array}$ \\
\hline $\begin{array}{l}\text { Quiescent stem } \\
\text { cells }\end{array}$ & $\begin{array}{l}\text { Relatively quiescent intestinal stem cells capable of crypt } \\
\text { repopulation upon injury }\end{array}$ & Lrig1 antibody/lineage tracing & Powell et al. (2012) \\
\hline
\end{tabular}

elevated barrier properties are due to the fact that the Caco-2 lines originated from the large intestine and also have an average tight junction pore radius of $3.7 \AA$, compared with $8-$ $13 \AA$ Á for native human small intestine (Tavelin et al. 2003). Caco-2 cell-based assays have other limitations such as (a) weak expression of important intestinal metabolic enzymes such as cytochrome P450 (CYP) 3A (Eric Le Ferrec et al. 2001), (b) lack of the crypt-villus axis which is important for fluid and ion transport, and (c) the absence of mucusproducing cells (Huang and Adams 2003). Another drawback of Caco-2 cell-based assays is that the high passages used in many laboratories induce variable expression levels of differentiation markers and transporters (Briske-Anderson et al. 1997; Behrens et al. 2004). The heterogeneity of the cell line, variability of the clones used by different researchers, and the passage numbers make it difficult to generate reproducible results among research laboratories.

To overcome some of the limitations of Caco-2 cultures, there have been numerous attempts to clone and re-clone Caco-2 cells to select clones with increased and enhanced drug transport rates (Woodcock et al. 1991). Even though
Caco-2 cells have been used as a model for pharmacological and toxicological studies, the expression of specific transporters and ion channel genes often differs from that of the human small intestine which complicates the interpretation of results (Anderle et al. 2003). Although Caco-2 is widely used for ADME studies in many labs, the model is composed only of enterocyte-like cells and lacks additional functional cells types. To compensate, a mixed culture of Caco-2 and methotrexate-treated HT29 colon adenocarcinoma cells, which are known to produce mucus, has been developed to mimic an enterocyte and goblet cell co-coculture system. To further increase functional complexity of Caco- 2 cultures, researchers have also used triple co-cultures of Caco-2 cells, HT29 cells, and the Raji B cell line (to mimic M-cells) for pharmacokinetic studies (Araújo and Sarmento 2013; LozoyaAgullo et al. 2017). However, these improvements increase the variability of results obtained by different laboratories.

Primary Human Three-Dimentional (3D) Tissue Models An in vitro small intestinal 3D tissue model needs to closely resemble the human intestinal epithelium structurally and 
phenotypically by comprising the different cell types of the intestinal epithelium. The model should show architectural similarity, physiological properties, and the functions of the human counterpart. In addition, the tissue model should be able to be cultured for long periods (Costa and Ahluwalia 2019). The most common primary human $3 \mathrm{D}$ intestinal tissue models include explants, organoids, and organotypic intestinal tissues as discussed in the following sections.

Intestinal Explants: The use of porcine intestinal tissue as a predictive model for human intestinal absorption has been demonstrated by the Netherlands Organization for Applied Scientific research (TNO). Recently, TNO has also utilized ex vivo human intestinal tissue in a newly developed InTESTine $^{\mathrm{TM}}$, two-compartment disposable device for drug absorption studies (Stevens et al. 2019). These models have been utilized to rank order compound permeability and to study metabolism at TNO. Even though explant tissues from multiple donors reflect the variability of the human population, the scarcity of normal human tissue and their short survival time ex vivo make their use infeasible for meeting the needs of modern-day drug development programs, which need to screen large numbers of compounds for safety and efficacy. Also, donor-to-donor variability makes the results from explant studies difficult to utilize in a predictive manner.

Small Intestinal Organoid Models: In recent years, progress has been made in the development of models generated from normal primary cells isolated from small intestine tissues which are more relevant for modeling the complex biological processes of the native tissue. The key innovation was the development of methods for cultivating mouse and human intestinal organoids from stem cells isolated from intestinal crypts (Sato et al. 2009; Spence et al. 2011). The importance of Wnt signaling was identified and a cocktail of growth factors was developed to allow the maintenance and expansion of Lgr5+ stem cells and further formation of enteroids (intestinal organoids). Also, analogous intestinal organoids were developed from embryonic stem cells or induced pluripotent stem cells (Ogaki et al. 2015). Both types of organoids contain the major cell types found in the small intestine, including enterocytes, Paneth cells, goblet cells, and enteroendocrine cells. These organoids recapitulate many of the normal processes of the intestinal mucosa and allow study of phenomena such as intestinal toxicity, immune reactions, and interactions with microbiota (Leslie et al. 2015; Lu et al. 2017; BarEphraim et al. 2020). Organoids can also be generated from patients with various pathological conditions, such as inflammatory bowel disease or from individuals with various genetic backgrounds (Dekkers et al. 2013; VanDussen et al. 2015). Organoids from individuals with cells of varying genetic make-up opens a plethora of possibilities for designing of idiosyncratic therapies and personalized medicine (reviewed in Park et al. 2018; Lehle et al. 2019). Nonetheless, there are disadvantages associated with the physical organization of organoids. The villi face inward which means that direct access of test compounds to the apical surface of the enterocytes to mimic luminal exposure is not possible. Likewise, apicalto-basolateral drug permeation studies cannot be performed or depend on microinjecting the test articles into the organoid. The need for microinjection can be avoided by the use of recently developed "apical-out" enteroids following manipulating extracellular membrane (ECM) components in the culture system which resulted in enteroid polarity reversal (Co et al. 2019). Such apical-out organoids may allow to examine (a) drug-drug interactions following co-administration of drugs, (b) drug metabolism on the exposure site (apical surface), and (c) pathogen exposure. However, this polarity reversal was achieved in a suspension cell culture system and it is not clear if these organoids will form a continuous epithelial structure in Transwell inserts. Others have also addressed this limitation by converting colon spheroids $2 \mathrm{D}$ cultures into Transwell inserts. Following dissociation of 2D systems into single cells, the cells were seeded onto Transwell ${ }^{\circledR}$ inserts. However, these cultures did not form villi or similar secondary structures and their TEER was relatively high $\left(\sim 400 \Omega \mathrm{cm}^{2}\right)$ (VanDussen et al. 2015) which is more similar to the colon epithelium than the small intestine.

A group from the Wyss Institute, Harvard University, has developed human small intestine-on-a-chip tissues containing epithelial cells that were isolated from intestinal duodenal biopsies. The primary epithelial cells were expanded as 3D organoids, dissociated, and cultured on a porous membrane within a microfluidic device with human intestinal microvascular endothelial cells (Kasendra et al. 2018). The intestinal tissue model was shown to form villi-like projections lined by polarized epithelial cells that undergo multi-lineage differentiation similar to organoids. Positive aspects of the system include an open lumen apical surface, an interface with the endothelium, and media flow. Transcriptomic analysis also indicated that the intestine-on-a-chip more closely mimics the human duodenum when compared with the duodenal organoids. However, the model is not currently commercially available to the broader scientific community.

3D Organotypic Tissue Models: While organoids exhibit an inward growth of the luminal surface, 3D organotypic tissue models have an open luminal surface which makes them ideal for topical application of test compounds mimicking in vivo oral exposure. Organotypic models are able to recreate the architectural features and physiology of native human intestinal tissue and hence are more relevant than Caco-2 or animal models. Besides the ethical advantages of organotypic models over the live animals, these tissues have better biological relevance in terms of translational ability of human responses and their potential to simulate specific conditions such as drug absorption, metabolism, pathogen infection, and inflammation. These organotypic tissue models allow study of the molecular aspects of each process and help 
"deconstructing" biological processes to study them with variable levels of complexity. For example, one can study the effect of a substance on isolated intestinal mucosa, intestinal mucosa together with immune cells, or combine the intestine with a liver-on-a-chip model and observe what happens once the test compound undergoes metabolic changes. The current in vitro intestinal tissue models utilize either cell lines or primary intestinal cells.

Human Primary Cell-Based Organotypic Small Intestinal Tissue Models: The development of a human primary cellbased tissue model to accurately predict drug safety and efficacy remains a major challenge for the pharmaceutical industry (Li 2005). However, the availability of MatTek's small intestinal tissue model (EpiIntestinal ${ }^{\mathrm{TM}}$, MatTek Corporation, Ashland, MA) is a significant development in studying ADME of pharmacological drugs (Ayehunie et al. 2018). Two types of EpiIntestinal models have been developed by MatTek.

Organotypic epithelial tissue models are produced by seeding small intestinal epithelial cells onto cell culture inserts (MatTek Corp.) and culturing at air liquid interface (ALI) for up to $14 \mathrm{~d}$ to form a partial-thickness intestinal tissue model. During this culture period, the cultures stratify, differentiate, and form a distinct apical-basolateral polarity. The polarized organotypic small intestinal partial thickness tissues form "villi-like" structures and express the efflux transporters such as $\mathrm{P}$-glycoprotein (P-gp) breast cancer resistance protein (BCRP) (Ayehunie et al. 2018).

A more complex organotypic tissue model is the fullthickness intestinal tissue which comprises intestinal epithelial cells and intestinal fibroblasts. To reconstruct the fullthickness tissue, a mixture of primary epithelial cells and fibroblasts is seeded onto the microporous membrane of tissue culture inserts under submerged and then at ALI conditions for $14 \mathrm{~d}$. In this model, the epithelial cells and fibroblasts selfassembled in the correct orientation and form a distinct and polarized tissue structure with an apical epithelial architecture on top of a fibroblast substrate (Fig. 1). Unlike the partialthickness intestinal models, these cultures show deposition of extra-cellular matrix (ECM) proteins of collagen IV and fibronectin that emanated from the epithelial-fibroblast co-culture system (Peters et al. 2019).

The structure of EpiIntestinal tissue shows a well polarized geometry and the tissue forms villi (Fig. 1), microvilli, brush borders (Fig. 2), and tight junctions that mimic the in vivo counterpart. These tissues can be cultured for up to $42 \mathrm{~d}$ at ALI and can have utility for repeat dose applications (Peters et al. 2019). These organotypic small intestinal tissues can be reconstructed in 24 single-well cell culture inserts or in a 96well plate format for high throughput applications. Even though, the standard EpiIntestinal model is reconstructed using epithelial cells from the ileum section of the gut, organotypic tissues from the duodenum and jejunum segments of the small intestine have also been developed (Ayehunie, unpublished). The availability of the models from the different segments of the small intestine will help address questions regarding the contribution of each segment in drug pharmacokinetics studies.

One of the attractive features of the organotypic tissue models is that they express efflux transporters and drugmetabolizing enzymes that mimic in vivo intestinal tissues. For instance, RT-PCR analysis showed that the tissue models expressed drug-metabolizing enzymes (e.g., CYP3A4, CYP3A5, CYP2C9, and CYP2C19 and GSTs) and the efflux transporters (e.g., P-gp/MDR1, MRP1, MRP-2, and BCRP), which are known to be present on walls of human intestinal tissue. The activity of the drug transporters and drugmetabolizing enzymes, MDR1, P-gp, BCRP, CYP3A4, CYP2J2, UDP-glucuronosyltransferases (UGT), and carboxylesterases (CES) on the intestinal organotypic tissue models was confirmed using functional assays with selective substrates and inhibitors. In this study, the authors concluded that EpiIntestinal tissues provide a more holistic model for the investigation of drug absorption and metabolism in human gastrointestinal tract compared with Caco-2 cells (Cui et al. 2020).

These organotypic tissue models allow the evaluation of lot-to-lot reproducibility using endpoints such as transepithelial electrical resistance (TEER) and the LY leakage assay, both of which monitor the barrier integrity of the organotypic intestinal tissues. For instance, TEER values of 90-300 $\Omega \mathrm{cm}^{2}$ and LY leakage $<4 \%$ were applied as QC acceptance criteria for EpiIntestinal tissues (MatTek Corporation). The mean TEER values for the partial thickness, full-thickness 24-well format, and 96-well formats were shown to be $150 \pm 8.6 \Omega \mathrm{cm}^{2}$ ( $N=129$ lots), $175 \pm$ $12.3 \Omega \mathrm{cm}^{2}$ ( $N=201$ lots), and $162 \pm 10.8 \Omega \mathrm{cm}^{2}$ ( $N=68$ lots), respectively, which is close to physiological values.

Use of 3D Organotypic Intestinal Tissue Models to Predict Drug Absorption and Metabolism: The utility of the EpiIntestinal model to rank order the permeability of three model drugs, representative of low $(<50 \%$, talinolol), moderate (50-84\%, ranitidine), and high ( $\geq 85 \%$, warfarin) absorption in humans, was demonstrated (Ayehunie et al. 2018). Drug permeation data obtained from EpiIntestinalFT and Caco-2 cells were also compared with historical data of $\%$ fraction absorbed in humans. The results showed that the EpiIntestinalFT data correlated better with human absorption data $\left(r^{2}=0.91\right)$ compared with Caco-2 cells $\left(r^{2}=0.71\right)$ (Ayehunie et al. 2018). The study was expanded further to analyze the permeation of 28 drugs with diverse absorption properties. Permeability coefficients determine with the EpiIntestinal tissues were compared with historical data for the fraction-absorbed $(\mathrm{Fa})$ values observed in humans (Table 2 ). Using an apparent permeability coefficient $\left(P_{\text {app }}\right)$ value of $5 \times 10^{6}$ as a cutoff, the Epilntestinal tissues were able 

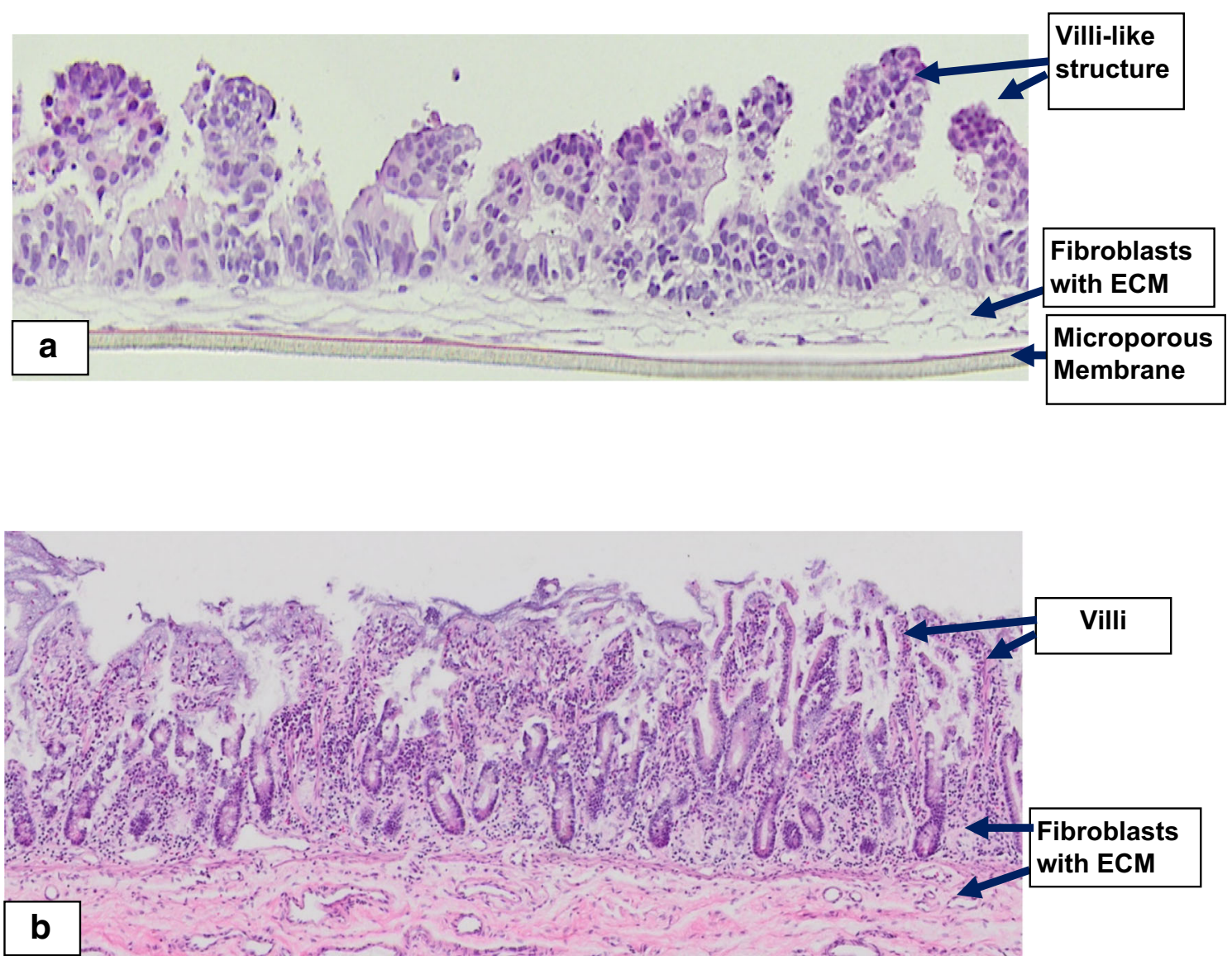

Figure 1. H\&E stained histological cross-section of the full-thickness EpiIntestinal tissue model $(a)$ and the in vivo explant small intestine $(b)$ showing the apical epithelium with villi structure and the underline structure of fibroblast-containing collagen matrix. Note: The EpiIntestinal tissue was grown on an underlying microporous membrane (pore diameter $=0.4 \mu \mathrm{m}$ ). to classify test articles as high $\left(P_{\text {app }}>5 \times 10^{6}\right)$ permeability or low permeability drugs $\left(P_{\text {app }}<5 \times 10^{6}\right)$, which correlated well with historical absorption data in humans (Table 2; Ayehunie et al. 2018). Overall, the reconstructed intestinal tissue model was able to differentiate flux of high vs low permeability compounds, and monitor drug-drug interactions, and metabolism (Ayehunie et al. 2018; Cui et al. 2020).

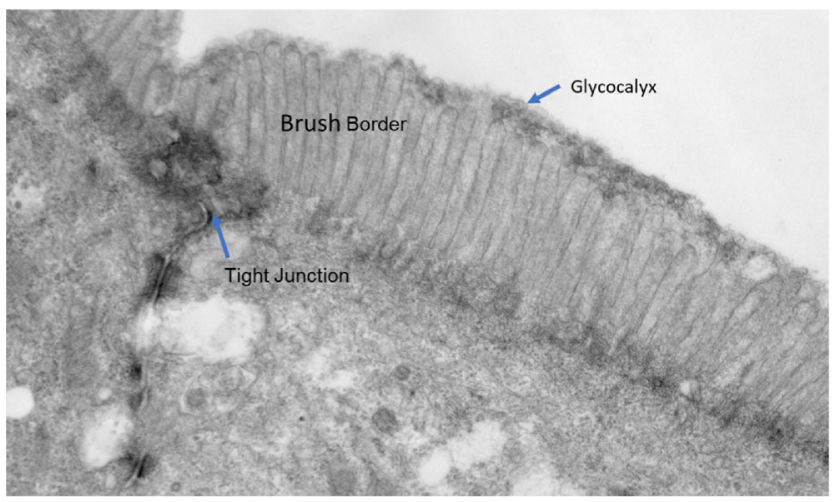

Figure 2. Transmission electron microscopy (TEM) images showing brush borders and a tight junction in the EpiIntestinal tissue model.
In another study, the effect of enhancers on the permeation of low permeability drugs was demonstrated using the EpiIntestinal tissue model. Complexing the low permeability, idiopathic pulmonary fibrosis drug, Nintedanib, with cyclodextrin was shown to significantly increase absorption and bioavailability across the intestinal barrier (Vaidyaa et al. 2019). Recently, Marrella et al. (2020) utilized in a flow system to monitor the absorption of two non-metabolized sugars, lactulose and mannitol, in EpiIntestinal tissues grown under standard (healthy) and pathological conditions (EGTA-induced barrier disruption). The ratio of lactulose-to-mannitol in urine samples is a clinical test used to assess disorders characterized by changes in gut permeability (Johnston et al. 2000), and this kinetics was well recapitulated in the closed circuit hosting EpiIntestinal tissue (Marrella et al. 2020).

Since metabolism and facilitated transport are key components in the assessment of oral drug absorption and bioavailability, drug-metabolizing enzymes and transporters play an important role in determining the pharmacokinetics, safety, and efficacy profiles of drugs (International Transporter Consortium et al. (2010). In this regard the in vitro 3D organotypic intestinal tissue models are emerging as a 
predictive tool to examine drug bioavailability, drug-drug interaction, and drug biotransformation.. For instance, apical (A-B) exposure of the EpiIntestinal tissues to the drugs $(10 \mu \mathrm{M}$ of midazolam or fosphenytoin for $2 \mathrm{~h})$ resulted in conversion of the parent drug Midazolam to its metabolite, alpha-hydroxymidazolam ( $6.5 \%$ conversion), and the parent drug Fosphenytoin to its metabolite, Phenytoin $(57.2 \%$ conversion), verifying the functionality of the Cytochrome P450 (CYP) 3A4 enzyme (Ayehunie, manuscript in preparation). Recently, relevant drug transporters and drug-metabolizing enzymes, including MDR1 (P-gp), BCRP, CYP3A4, CYP2J2, UDP-glucuronosyltransferases (UGT), and carboxylesterases (CES), were detected in functional assays with selective substrates and inhibitors (Cui et al. 2020). In this study, the selective BCRP inhibitor Ko-143 (3 $\mu \mathrm{M})$ strongly reduced the efflux of rosuvastatin by 32.2 -fold compared with the no inhibitor control. Additionally, a substantial amount of 1-hydroxymidazolam, the CYP3A4-selective metabolite of midazolam, was detected in EpiIntestinal tissues and this conversion was suppressed by the addition of the selective CYP3A4 inhibitor, CYP3cide. In comparison, only a negligible amount of the metabolite was detected in Caco-2 cultures. In order to profile the metabolism capacity of EpiIntestinal tissues the investigators further study the metabolic pathway of the double pro-drug Dabigatran etexilate. Dabigatran etexilate is known to be first hydrolyzed by CES1 into BIBR 1087 and the formation of the active drug BIBR 953 from the intermediate metabolite BIBR 1087 is catalyzed by CES2 (predominantly expressed in human intestine). Interestingly, Dabigatran etexilate was metabolized to

Table 2. Drug permeation $(\mathrm{A} \rightarrow \mathrm{B}$ and $\mathrm{B} \rightarrow \mathrm{A}$ ) and efflux ratio (ER) of model drugs tested in EpiIntestinal tissues. Data show active efflux, ER $>2$ fold. Applied drug concentration was $10 \mu \mathrm{M}$ for $2 \mathrm{~h}$

\begin{tabular}{|c|c|c|c|c|c|c|c|c|}
\hline & \multicolumn{8}{|c|}{ Average ( $N=2-5$ experiments) } \\
\hline & Mean $\mathrm{A} \rightarrow \mathrm{B}$ & $P_{\text {app }}$ & Mean $\mathrm{B} \rightarrow \mathrm{A}$ & $P_{\text {app }}$ & Efflux ratio & Reproducibility & Human (historical values) & \\
\hline Test article & $\left(10^{-6} \mathrm{~cm} \mathrm{~s}^{-1}\right)$ & $\begin{array}{l}\mathrm{St} \\
\mathrm{de}- \\
\mathrm{V}\end{array}$ & $\left(10^{-6} \mathrm{~cm} \mathrm{~s}^{-1}\right)$ & $\begin{array}{l}\text { St } \\
\mathrm{de}- \\
\mathrm{V}\end{array}$ & $\mathrm{B} \rightarrow \mathrm{A} / \mathrm{A} \rightarrow \mathrm{B}$ & Repeat lots & $\begin{array}{l}\text { Fraction absorbed in humans } \\
\quad(\%)\end{array}$ & BCS classification \\
\hline Carbamazepine & 19.7 & 1.9 & 32.6 & 3.4 & 1.7 & $N=3$ & 97 & High \\
\hline Citalopram & 15.9 & 1.3 & 25.0 & 0.5 & 1.6 & $N=2$ & 90 & High \\
\hline Digoxin & 1.1 & 0.6 & 3.6 & 0.5 & 3.1 & $N=2$ & 81 & $\begin{array}{r}\text { Low/efflux } \\
\text { substrate }\end{array}$ \\
\hline Midazolam & 11.1 & 0.4 & 34.1 & 11.7 & 3.1 & $N=2$ & 90 & High \\
\hline Metoprolol & 8.4 & 2.4 & 22.6 & 3.2 & 2.7 & $N=5$ & 95 & High \\
\hline Metronidazole & 14.0 & 4.0 & 18.8 & 1.9 & 1.3 & $N=3$ & 80 & Low/high \\
\hline Mycophenolate & 12.8 & 2.3 & 10.7 & 1.2 & 0.8 & $N=2$ & 94 & High \\
\hline Naproxen & 15.5 & 3.8 & 19.4 & 2.6 & 1.3 & $N=2$ & 98 & High \\
\hline Omeprazole & 12.2 & 5.2 & 24.9 & 6.5 & 2.0 & $N=3$ & 88 & High \\
\hline Propranolol & 8.4 & 4.4 & 25.9 & 2.0 & 3.1 & $N=3$ & 90 & High \\
\hline Quinidine & 8.0 & 2.4 & 17.0 & 1.6 & 2.1 & $N=3$ & 80 & High \\
\hline Verapamil & 5.7 & 2.8 & 25.6 & 5.4 & 4.5 & $N=3$ & 100 & High \\
\hline Warfarin & 18.8 & 4.8 & 9.1 & 2.2 & 0.5 & $N=4$ & 98 & High \\
\hline Acyclovir & 0.3 & 0.0 & 1.1 & 0.1 & 3.4 & $N=3$ & 30 & Low \\
\hline Amoxicillin & 0.6 & 0.4 & 1.1 & 0.9 & 1.8 & $N=2$ & 77 & Low/high \\
\hline Atenolol & 0.7 & 0.4 & 1.1 & 0.6 & 1.5 & $N=5$ & 50 & Low/moderate \\
\hline Cimetidine & 1.9 & 0.2 & 1.5 & 0.4 & 0.8 & $N=3$ & 62 & Low \\
\hline Ethambutol & 0.8 & 0.7 & 0.6 & 0.1 & 0.8 & $N=3$ & 75 & Low \\
\hline Enalapril & 0.5 & 0.3 & 0.7 & 0.5 & 1.4 & $N=5$ & 40 & Low/moderate \\
\hline Erythromycin & 0.6 & 0.4 & 2.5 & 0.8 & 4.5 & $N=3$ & 35 & Low \\
\hline Furosemide & 0.7 & 0.3 & 4.9 & 0.7 & 7.0 & $N=3$ & 61 & Low/moderate \\
\hline Metformin & 1.3 & 0.5 & 1.3 & 1.6 & 1.0 & $N=4$ & 71 & Low/moderate \\
\hline Methotrexate & 0.8 & 0.5 & 0.7 & 0.5 & 0.9 & $N=5$ & 20 & Low/Moderate \\
\hline Ranitidine & 1.1 & 0.6 & 1.3 & 0.2 & 1.2 & $N=3$ & 61 & Low/moderate \\
\hline Raloxifene & 1.9 & 0.1 & 3.1 & 0.8 & 1.7 & $N=2$ & 60 & Low \\
\hline Rosuvastatin & 0.4 & 0.1 & 7.0 & 3.4 & 16.7 & $N=2$ & 20 & Low \\
\hline
\end{tabular}


the active drug, BIBR953, through the intermediate BIBR 1087 by EpiIntestinal tissues similar to that observed in vivo, suggesting the involvement of functional CES2 esterase enzyme. These results indicate that the EpiIntestinal tissues mimic drug metabolism in the human small intestine and likely will be more predictive than Caco-2 cells which lack key drug-metabolizing enzymes found in native tissue. It is anticipated that the 3D human organotypic small intestinal model can play a role in narrowing the gap from preclinical to clinical translation of results.

In summary, the drug-metabolizing enzymes and drug transporters expressed in the 3D-human intestinal tissue models make them appropriate for studies involving (a) bidirectional drug transport from apical (A) to basolateral (B) or B-to-A), (b) drug-drug interaction, and (c) drug metabolism studies. Compared with animal studies, the in vitro intestinal models will be more cost-effective and will allow for high throughput screening. These models will be useful for optimizing compound formulations and predicting metabolism and bioavailability of orally administered drugs at an early stage of the drug development process. Additional evaluation by transcriptomic, proteomic, metabolomic, and functional endpoints will increase confidence in the use of intestinal models for pharmacokinetic studies (Sawant-Basak et al. (2018).

Drug Toxicity Studies Drug-induced gastrointestinal toxicity (DIGT) is among the most frequently occurring adverse effects in clinical studies (Peters et al. 2020). To date, no specific mechanistic diagnostic/prognostic biomarkers or translatable preclinical models of DIGT exist (Carr et al. 2017). Therefore, predicting toxicity of candidate and investigational drugs is of paramount importance in the preclinical stage of drug development (Stevens and Baker 2009). Currently, preclinical toxicity testing heavily depends on the animal models. However, animal models, in particular rodents, show very low predictability for DIGT adverse effects. Better predictions can be made in canine and non-human primate models; however, due to cost, these species are often only used in later stages of drug development (Olson et al. 2000). To overcome challenges of determining DIGT at the preclinical stage, in vitro models can be used as a promising alternative to animal testing (Peters et al. 2019). For example, AstraZeneca tested a validation set of 31 widely prescribed drugs with the EpiIntestinal tissue model. Using TEER as a measure of barrier function, a threshold value was established that distinguished between drugs that induced clinical diarrhea from those which were well-tolerated. The in vitro study gave a predictive accuracy of $80 \%$ which matches the translation accuracy of in vivo studies in higher-order species. The predictivity was much higher for parallel experiments performed with Caco-2-based model (Peters et al. 2019). In other experiments on a limited set of other drugs which had failed in clinical trials, the EpiIntestinal TEER-based assay more accurately predicted the maximum tolerated dose than was predicted based on 1 mo-long animal studies (rats and dogs). The authors concluded that the EpiIntestinal tissue model is the first in vitro assay with validated predictivity for diarrheainducing drugs and suggested its potential utility for lead optimization, dose schedule exploration, and clinical translation (Peters et al. 2019).

Nanoparticle Toxicity Recently, there has been a dramatic increase in the use of engineered nanoparticles (ENPs) in a broad range of products. ENPs introduced into the body through food, drink, pharmaceutical formulations, or inadvertent ingestion leads to the increased exposure of all body systems including the GI tract, where there is a very limited amount of toxicological data (McCauley and Wells 2017). In vitro intestinal tissues represent a system that might allow rapid prescreening of the ingestible nanomaterial particles. Studies aimed at observing the toxic properties of copper nanoparticles such as $\left(\mathrm{CuO}\right.$ and $\left.\mathrm{CuSO}_{4}\right)$ on Epilntestinal tissues revealed a significant decrease in tissue viability of $30 \%$ and $75 \%$ for doses of $40 \mu \mathrm{g} / \mathrm{mL}$ and $80 \mu \mathrm{g} / \mathrm{mL}$, respectively, when exposed to $24 \mathrm{~h}$ time period (Henson et al. 2019). The authors also showed that EpiIntestinal tissues require higher concentrations of $\mathrm{CuO}$ to elicit a cytotoxic effect by $24 \mathrm{~h}$ compared with rat intestinal epithelial cell line (IEC-6, 2D intestinal model).

Recent experiments in our laboratory examined the effects of cupric(II) oxide $(\mathrm{CuO})(50 \mathrm{~nm})$, zinc oxide $(\mathrm{ZnO}, 35-$ $45 \mathrm{~nm})$, titanium oxide $\left(\mathrm{TiO}_{2}, 40 \mathrm{~nm}\right)$, and silver $(20 \mathrm{~nm}$, $30-50 \mathrm{~nm}$, and $80-100 \mathrm{~nm}$ ) nanoparticles on the EpiIntestinal tissues following $24 \mathrm{~h}$ exposure to different concentrations of these ENPs by monitoring (1) barrier integrity (TEER), (2) tissue viability (MTT assay), (3) oxidative stress (8-isoprostane release), and (4) inflammatory response (IL-8). The results showed a dose-dependent reduction of the tissue barrier and viability following exposure to $\mathrm{CuO}, \mathrm{ZnO}$, and single wall carbon nanotubes (SWCNT). The analysis of culture supernatants collected at $24 \mathrm{~h}$ also showed a dosedependent release of IL- 8 for $\mathrm{CuO}$ and $\mathrm{ZnO}$ and the oxidative stress indicator 8-isoprostane for $\mathrm{CuO}$ (Ayehunie, manuscript in preparation). Silver nanoparticles showed no acute adverse effects on the intestinal microtissues in vitro, which was consistent with in vivo observations (Burdus et al. 2018). In summary, the EpiIntestinal tissue model appears useful as a preclinical screening tool to examine the toxicity profile of ingested nanoparticles and to improve the design of nanoparticle-based therapeutic formulations or personal care products.

Intestinal Inflammation: Epithelial tissues exposed to chemicals, drugs, ligands, antigens, and cytokines have been shown to undergo quantitative changes in inflammatory responses and epithelial permeability. These inflammatory 
Figure 3. Cytokine/chemokine gene expression levels following treatment of EpiIntestinal tissues with $\mathrm{T}$ cell cytokines (interferon gamma and IL-17 A/F).
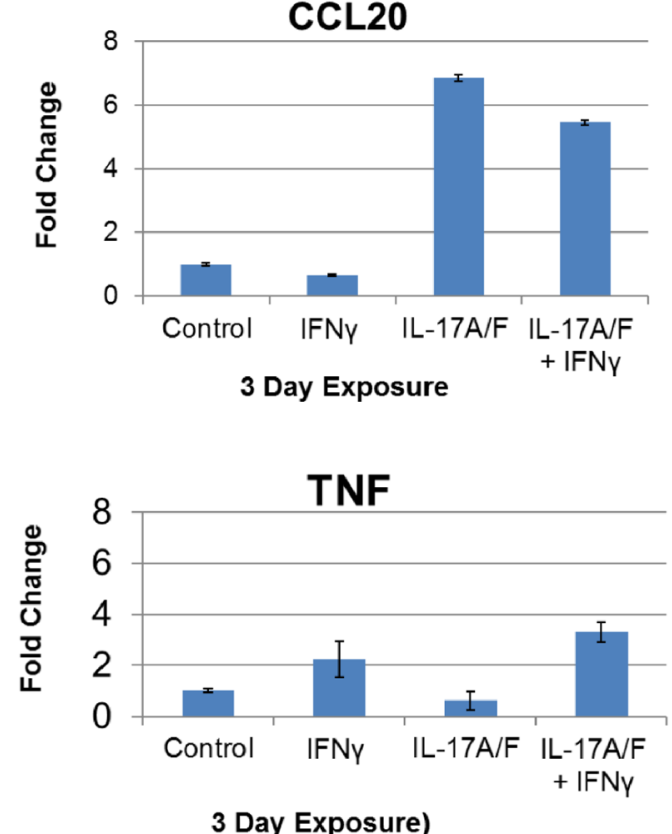

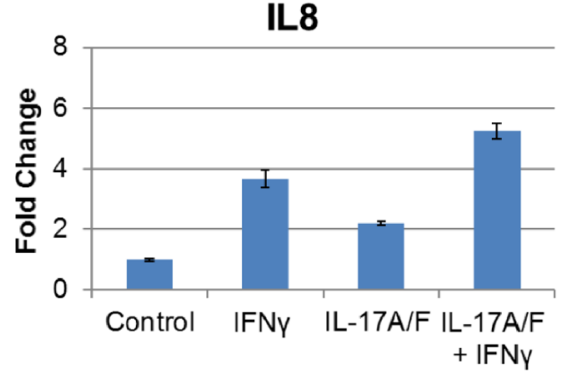

3 Day Exposure

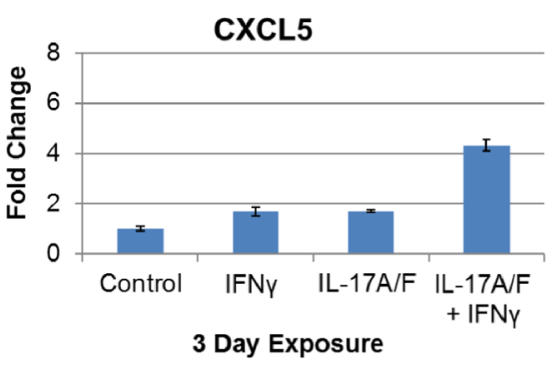

responses could (1) exacerbate cytokine/chemokine release, (2) alter drug-metabolizing enzymes and ABC transporter expression levels, and/or (3) compromise the epithelial barrier by affecting tight junctions. To examine the effect of cytokines on innate immune responses, the EpiIntestinal tissues were treated with IFN- $\gamma$, IL-17A/F, or IL-17A/F plus IFN- $\gamma$ and changes in gene expression levels for the proinflammatory cytokines, CCL-20, IL-8, TNF- $\alpha$, and CXCL5, were monitored. The results showed increases in IL- $8, \mathrm{TNF}-\alpha$, and CXCL5 in a synergetic manner (Fig. 3). In another study, the impact of IL-6 on drug-metabolizing enzymes and transporters was investigated using the EpiIntestinal tissue model. mRNA expression levels of inflammatory response receptors, drug-metabolizing enzymes (phase I and phase II), drug transporters, and nuclear transporters were impaired when the EpiIntestinal tissues were exposed to the proinflammatory cytokine IL-6 $(5-20 \mathrm{ng} / \mathrm{mL}$ ) for $72 \mathrm{~h}$ (Simon et al. 2019). The authors showed that exposure of EpiIntestinal tissues to IL-6 can have downstream effects in reducing CYP450 mRNA expression such as CYP2C19, CYP2C9, and CYP3A4 by 40-50\% with a decrease in activity level of $20-75 \%$. Such observations may have important implications in relation to the effect of released inflammatory cytokines in presystemic metabolism and dosage application.

Data from another study suggested that IL-22 may contribute to tissue inflammation in certain mouse models (Kamanaka et al. 2011). Using the EpiIntestinal model, the function of IL-22 on the regulation of intestinal epithelium

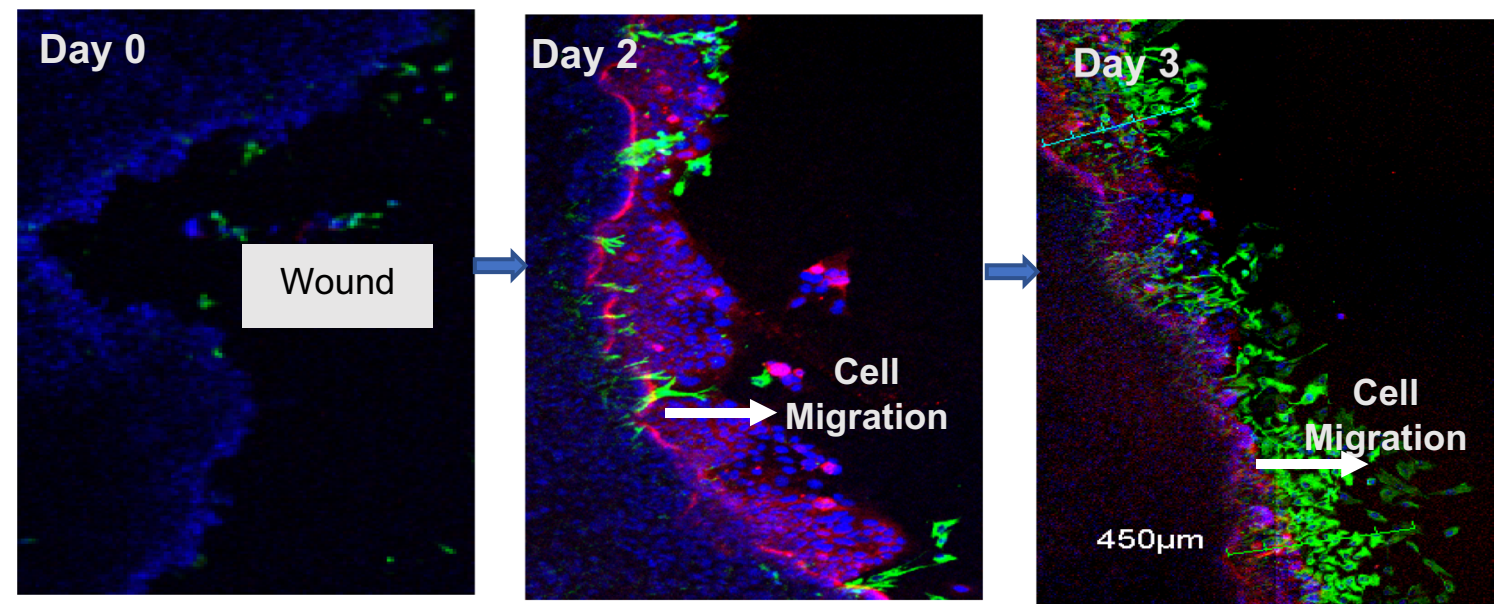

Figure 4. Migrating epithelial cells stained with cytokeratin-19 (red), fibroblasts stained for vimentin (green), and nuclei stained with DAPI (blue) after wounding of full-thickness intestinal tissues (EpiIntestinalFT) with $2 \mathrm{~mm}$ biopsy punch and cultured for $3 \mathrm{~d}$. Note: On day 3, the fibroblasts are at the leading edge of the resealing wound. 
Figure 5. Histology of EpiIntestinalFT showing tissue restitution over a 6-d period after wounding. Initial migration of leading cells over the wounded section of the tissue was noted on day 2 post-wound, black arrow) and complete resealing of the wound and tissue differentiation occur on day 6 .
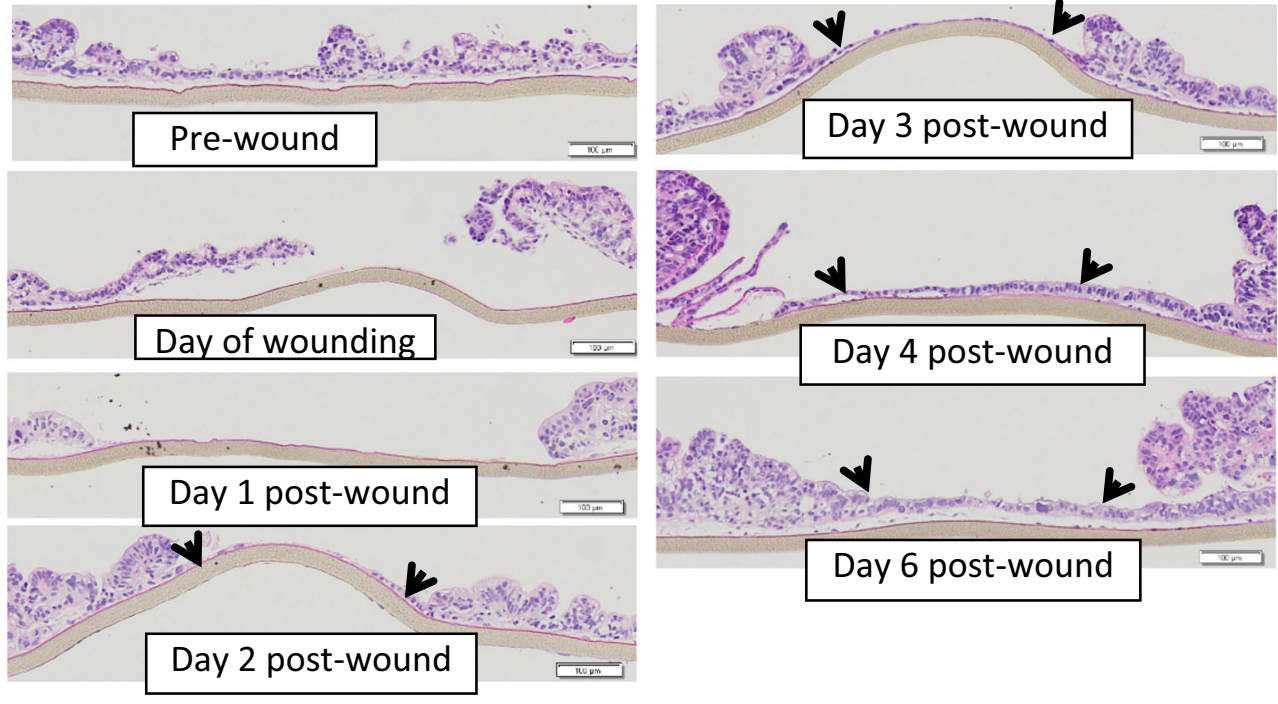

barrier was examined. The investigators found that exposure of EpiIntestinal tissues to IL-22 (100 ng/mL) for $24 \mathrm{~h}$ significantly induced the expression of Claudin-2, a cation-pore/ channel-forming tight junction protein through the Janus kinase-signal transducer and activator of transcription (JAK/ STAT) signaling pathway. Upregulation of the pore forming claudin- 2 by IL-22 led to reduced transepithelial TEER and increased paracellular intestinal epithelial permeability of ions (Wang et al. 2017). The researchers also noted that IL-22 signals exclusively through the basolateral side of the polarized tissues.

Repeated epithelial damage or injury is also implicated in intestinal disorders including inflammatory bowel disease. Rapid closure or resealing of wounds has key physiological importance and is a natural defense mechanism against such damage. The process of intestinal epithelial restitution and the various factors that contribute to gut homeostasis and intestinal epithelial wound healing following injury have been reviewed in detail by Lizuka and Konno (2011) using rat IECs (IEC-6) cell culture system. In this system, the epithelial cells found in the wounded area are thought to have migrated into the wound in a process of restitution which involves reorganization of the actin cytoskeleton. To recapitulate in vivo wound repair, the EpiIntestinal tissue was wounded using a 2-mm biopsy punch. The wounded tissues were maintained in culture and time dependent healing was noted. On day 2 post-injury, epithelial cells were found at the leading edge of the wound and on day 3 , fibroblasts had

Table 3. Comparisons of intestinal organoids and organotypic tissue culture systems

\begin{tabular}{|c|c|c|}
\hline Parameter & Organoid & Organotypic tissue models \\
\hline Size and shape & Undefined & Defined tissue diameter \\
\hline $\begin{array}{l}\text { Culture condition and Epithelial } \\
\text { differentiation }\end{array}$ & Embedded in Matrigel; inward villi growth & $\begin{array}{l}\text { Wall-to-wall polarized tissue growth } \\
\text { with accessible apical "luminal" } \\
\text { and basolateral surface }\end{array}$ \\
\hline Drug application & $\begin{array}{l}\text { Access to apical side is difficult (microinjection } \\
\text { needed) }\end{array}$ & $\begin{array}{l}\text { Allows access to apical and basal sides } \\
\text { for drug permeation studies }\end{array}$ \\
\hline Barrier integrity measurement & Not quantifiable & $\begin{array}{l}\text { Quantified by TEER measurement and } \\
\text { leakage experiments such as Lucifer yellow } \\
\text { leakage }\end{array}$ \\
\hline Intestinal restitution/wound healing & Difficult to model & Can be modeled \\
\hline Quality control data & Not standardized & Standardized \\
\hline Patient-specific disease modeling & Possible & Difficult \\
\hline Intestinal cell phenotypes & Expressed & Majority expressed \\
\hline Host-pathogen interaction studies & Yes & Yes \\
\hline Long-term culture & A year or more & Up to $6 \mathrm{wk}$ \\
\hline Cost & Expensive (due to growth factors) & Relatively inexpensive \\
\hline
\end{tabular}


expanded into the wound and epithelial cells had started to grow on the fibroblasts. On day 4, the wound was reepithelized. By day 6, there was a complete intestinal restitution and differentiation of epithelial layer. The progress of the healing process was monitored by immunohistochemical staining and histological observation (Figs. 4 and 5).

Infectious Disease Modeling: Enteric pathogens which are the causative agents of diarrheal diseases are a significant public health burden in that they often result in hospitalization of the elderly ( $>65 \mathrm{yr}$ old) in developed nations and cause sickness or death in children and adults in developing countries (Phalipon and Sansonetti 2007; Schiller 2009). Humans and/or higher primates are the natural hosts for certain enteric pathogens (e.g., Shigella flexneri and the Norovirus; Ettayebi et al. 2016; Todd and Tripp 2019). Due to the cost and ethical issues associated with the use of higher primates, human intestinal tissues are ideal models to decipher cell-pathogen interactions and mechanisms of infection. In a recent study, the EpiIntestinal model was used to investigate the pathophysiology and mechanisms by which $S$. flexneri invades the intestinal epithelium. S. flexneri affects the columnar architecture of the villi of intestinal tissues accompanied by F-actin organizational disruption associated with cofilin activation (Maldonado-Contreras et al. 2017). Mechanistically, S. flexneri infection secretes serine protease A (SepA) which is responsible for the disruption of the intestinal epithelial barrier via the LIM kinase I (LIMK1) pathway (MaldonadoContreras et al. 2017) and which in turn is involved in negative inhibition of actin-remodeling proteins such as cofilin. Insights gained from these studies demonstrated the use of the in vitro intestinal tissues as a valuable enteric bacterial infection model to study molecular mechanisms or pathways involved in viral infection and to screen the safety and efficacy of candidate drugs against enteric pathogens. Most importantly, a tissue model that can be infected with human pathogens such as S. flexneri (causative agent of Shigellosis) is critically needed since humanized mouse models or xenotransplants of human fetal intestine to mice poorly reflect human responses and are time-consuming, expensive, and ethically problematic.

Although the main route of SARS-CoV-2 (causative agent of COVID-19 disease) transmission is generally accepted to be through the respiratory tract, emerging reports indicate that the intestinal tissue could be an important target organ that plays a role in SARS-CoV-2 infection and transmission. A review by He et al. (2020) showed potential existence of a "gut-lung" axis in SARS CoV-2 infection and pointed out that patients with gastrointestinal (GI) symptoms showed increased disease severity. Clinical studies show diarrhea to be one of the symptoms in patients infected with SARS-CoV-2 at a rate ranging from 2 to $50 \%$ of cases, indicating a potential role of the small intestine in COVID-19 infection and transmission (D'Amico et al. 2020). Recent studies have shown that the EpiIntestinal tissue model strongly expresses the ACE2 receptor along with TMPRSS2, both of which are essential for SARS-CoV-2 entry to target tissues (Wang et al. 2020). Clevers group and others also reported productive infection of SARS-CoV- 2 in ACE2 ${ }^{+}$mature enterocytes in human small intestinal organoids/enteroids, and infection was facilitated by TMPRSS 2 and TMPRSS4, by promoting SARS-CoV-2 spike fusogenic activity which may promote virus entry into host cells (Lamers et al. 2020; Zang et al. 2020). Hence, the role of the small intestinal organotypic and organoids in identifying biomarkers to predict SARS CoV-2 infection and transmission or disease severity needs further investigation.

\section{Conclusion}

The need for predictive in vitro intestinal models for drug absorption, metabolism, inflammation, drug-induced GI toxicity, disease modeling, and intestinal injury repair has led to the development of a variety of models that utilize animals, cell lines, ex vivo tissues, organoids, and organotypic small intestinal tissues. Emerging data show that organoids and organotypic tissue culture have polarized tissue architecture and physiological features and functions that recapitulate many of the in vivo small intestinal properties. Among the models, the EpiIntestinal tissues are found to be highly reproducible and are widely used by industry and academic institutions for basic and applied research. Although recent developments in intestinal organoid cultures have shown promise in translational research, the organoid culture format has limitations compared with 3D organotypic cultures (Table 3). Recently, the EpiIntestinal tissue model was able to identify with $>80 \%$ accuracy the commonly prescribed drugs that are known to induce clinical diarrhea. This predictive accuracy matches the translation accuracy of in vivo studies in higherorder species. Due to the presence of efflux transporters and drug-metabolizing enzymes, the organotypic intestinal tissue models can be used to predict drug absorption and metabolism to mimic responses of the human gastrointestinal tract and these models are more holistic compared with Caco-2 cells which lack major drug-metabolizing enzymes.

Funding Previously unpublished results presented herein for the EpiIntestinal tissue model were partially supported by grants by the National Institute of Health (NIH) from the National institute of General Medicinal Science (NIGMS, R44GM108164) and National Institute of Environmental Health Sciences (NIEHS, R43ES030648).

\section{References}

Anderle P, Rakhmanova V, Woodford K, Zerangue N, Sadée W (2003) Messenger RNA expression of transporter and ion channel genes in 
undifferentiated and differentiated Caco-2 cells compared to human intestines. Pharm Res 20:3-15

Araújo F, Sarmento B (2013) Towards the characterization of an in vitro triple co-culture intestine cell model for permeability studies. Int J Pharm 458:128-134

Artursson P, Ungell AL, Lofroth JE (1993) Selective paracellular permeability in two models of intestinal absorption: cultured monolayers of human intestinal epithelial cells and rat intestinal segments. Pharm Res 10:1123-1129

Ayehunie S, Landry T, Stevens Z, Armento A, Hayden P, Klausner M (2018) Human primary cell-based organotypic microtissues for modeling small intestinal drug absorption. Pharm Res 35:72

Balimane PV, Chong S (2005) Cell culture-based models for intestinal permeability: a critique. Drug Discov Today 10:335-343

Bar-Ephraim YE, Kretzschmar K, Clevers H (2020) Organoids in immunological research. Nat Rev Immunol 20:279-293

Barker N, van Es JH, Kuipers J, Kujala P, van den Born M, Cozijnsen M, Haegebarth A, Korving J, Begthel H, Peters PJ, Clevers H (2007) Identification of stem cells in small intestine and colon by marker gene Lgr5. Nature. 449(7165):1003-1007

Behrens I, Kamm W, Dantzig AH, Kissel T (2004) Variation of peptide transporter (PepT1 and HPT1) expression in Caco-2 cells as a function of cell origin. J Pharm Sci 93:1743-1754

Bland AP, Frost AJ, Lysons RJ (1995) Experimental disease susceptibility of porcine ileal enterocytes to the cytotoxin of Serpulina hyodysenteriae and the resolution of the epithelial lesions: an electron microscopic study. Vet Pathol 32:24-35

Briske-Anderson MJ, Finley JW, Newman SM (1997) The influence of culture time and passage number on the morphological and physiological development of Caco-2 cells. Proc Soc Exp Biol Med 214: 248-257

Burdus A-C, Gherasim O, Mihai A (2018) Biomedical applications of silver nanoparticles: an up-to-date overview. Nanomaterials 8:681

Carr DF, Ayehunie S, Davies A, Duckworth CA, French S, Hall N, Hussain S, Mellor HR, Norris A, Park BK, Penrose A, Pritchard DM, Probert CS, Ramaiah S, Sadler C, Schmitt M, Shaw A, Sidaway JE, Vries RG, Wagoner M, Pirmohamed M (2017) Towards better models and mechanistic biomarkers for druginduced gastrointestinal injury. Pharmacol Ther 172:181-194

Co JY, Margalef-Catala M, Li X, Mah AT, Kuo CJ, Monack DM, Amieva MR (2019) Controlling epithelial polarity: a human enteroid model for host-pathogen interactions. Cell Rep 26:25092520

Coors ME, Glover JJ, Juengst ET, Sikela JM (2010) The ethics of using transgenic non-human primates to study what makes us human. Nat Rev Genet 11:658-662

Corr SC, Gahan C, Hill C (2008) M-cells: origin, morphology and role in mucosal immunity and microbial pathogenesis. FEMS Immunol Med Microbiol 52:2-12

Costa J, Ahluwalia A (2019) Advances and current challenges in intestinal in vitro model engineering: a digest. Front Bioeng Biotechnol 18:144

Crawley SW, Mooseker MS, Tyska MJ (2014) Shaping the intestinal brush border destruction by enterohemorrhagic Escherichia coli (EHEC): new insights from organoid culture. J Cell Biol 207:441451

Cui Y, Claus S, Schnell D, Runge F, MacLean C (2020) In-depth characterization of Epilntestinal microtissue as a model for intestinal drug absorption and metabolism in human. Pharmaceutics 12:E405

Dame MK, Attili D, McClintock SD, Dedhia PH, Ouillette P, Hardt O, Chin AM, Xue X, Laliberte J, Katz EL, Newsome GM, Hill DR, Miller AJ, Tsai Y-H, Agorku D, Altheim CH, Bosio A, Simon B, Samuelson LC, Stoerker JA, Appelman HD, Varani J, Wicha MS, Brenner DE, Shah YM, Spence JR, Colacino JA (2018) Identification, isolation and characterization of human LGR5positive colon adenoma cells. Development 145(6):dev153049
D'Amico F, Baumgart DC, Danese S, Peyrin-Biroulet L (2020) Diarrhea during COVID-19 infection: pathogenesis, epidemiology, prevention and management. Clin Gastroenterol Hepatol 18:1663-1672

Dekkers JF, Wiegerinck CL, de Jonge HR, Bronsveld I, Janssens HM, de Winter-de Groot KM, Brandsma AM, de Jong NW, Bijvelds MJ, Scholte BJ, Nieuwenhuis EE, van den Brink S, Clevers H, van der Ent CK, Middendorp S, Beekman JM (2013) A functional CFTR assay using primary cystic fibrosis intestinal organoids. Nat Med 19: 939-945

Eric Le Ferrec FE, Christophe Chesne C, Artusson P, Brayden D, Fabre $\mathrm{G}$, Gires P, Guillou F et al (2001) In vitro models of the intestinal barrier. The report and recommendations of ECVAM Workshop 46. ATLA 29:649-668

Ettayebi K, Crawford SE, Murakami K, Broughman JR, Karandikar U, Tenge VR, Neill FH, Blutt SE, Zeng XL, Qu L, Kou B, Opekun AR, Burrin D, Graham DY, Ramani S, Atmar RL, Estes MK (2016) Replication of human noroviruses in stem cell-derived human enteroids. Science 353(6306):1387-1393

Fogh J, Fogh JM, Orfeo T (1977) One hundred and twenty-seven cultured human tumor cell lines producing tumors in nude mice. J Natl Cancer Inst 59:221-226

Gassler N (2017) Paneth cells in intestinal physiology and pathophysiology. World J Gastrointest Pathophysiol 8:150-160

Gonzalez L, Blikslager A, Ziegler A (2016) Large animal models: the key to translational discovery in digestive disease research. Cell Mol Gastroenterol Hepatol 2:716-724

Grasset E, Pinto M, Dussaulx E, Zweibaum A, Desjeux JF (1984) Epithelial properties of human colonic carcinoma cell line Caco-2: electrical parameters. Am J Phys 247:C260-C267

Gribble FM, Reimann F (2019) Function and mechanisms of enteroendocrine cells and gut hormones in metabolism. Nat Rev Endocrinol 15:226-237

Gupta V, Doshi N, Mitragotri S (2013) Permeation of insulin, calcitonin, and exenatide across Caco-2 monolayers: measurement using rapid 3-day system. PLoS One 8:e77136

He L-H, Ren L-F, Li J-F, Wu Y-N, Li X, Zhang L (2020) Intestinal flora as a potential strategy to fight SARS-CoV-2 infection. Front Microbiol 11:1388

Henson TE, Navratilova J, Tennant AH, Bradham KD, Rogers KR, Hughes MF (2019) In vitro intestinal toxicity of copper oxide nanoparticles in rat and human cell models. Nanotoxicology 13:795-811

Hilgendorf C, Spahn-Langguth H, Regårdh CG, Lipka E, Amidon GL, Langguth P (2000) Caco-2 versus Caco-2/HT29-MTX co-cultured cell lines: permeabilities via diffusion, inside- and outside-directed carrier-mediated transport. J Pharm Sci 89:63-75

Holmes R, Lobley RW (1988) Intestinal brush border revisited. Gut 30: $1667-1678$

Huang Y, Adams MC (2003) An in vitro model for investigating intestinal adhesion of potential dairy propionibacteria probiotic strains using cell line C2BBe1. Lett Appl Microbiol 36:213e216

Ideland M (2009) Different views on ethics: how animal ethics is situated in a committee culture. J Med Ethics 35:258-261

Igam Y et al (2019) Gastrointestinal tract 4: anatomy and role of the jejunum and ileum. Nurs Times 115(9):43-46

International Transporter Consortium, Giacomini KM, Huang SM, Tweedie DJ, Benet LZ, Brouwer KL, Chu X, Dahlin A, Evers R, Fischer V, Hillgren KM, Hoffmaster KA, Ishikawa T, Keppler D, Kim RB, Lee CA, Niemi M, Polli JW, Sugiyama Y, Swaan PW, Ware JA, Wright SH, Yee SW, Zamek-Gliszczynski MJ, Zhang L (2010) Membrane transporters in drug development. Nat Rev Drug Discov 9:215-236

Jiminez JA, Uwiera TC, Douglas Inglis G et al (2015) Animal models to study acute and chronic intestinal inflammation in mammals. Gut Pathog 7:29

Johnston SD, Smye M, Watson RGP, McMillan SA, Trimble ER, Love AHG (2000) Lactulose-Mannitol intestinal permeability test: a 
useful screening test for adult coeliac disease. Ann Clin Biochem 37: 512-519

Kamanaka M, Huber LA, Zenewicz N, Gagliani C, Rathinam W et al (2011) Memory/effector (CD45RB(lo)) CD4 T cells are controlled directly by IL10 and cause IL-22-dependent intestinal pathology. J Exp Med 208:1027-1040

Kasendra M, Tovaglieri A, Sontheimer-Phelps A, Jalili-Firoozinezhad S, Bein A, Chalkiadaki A, Scholl W, Zhang C, Rickner H, Richmond C, Li H, Breault DT, Ingber DE (2018) Development of a primary human small intestine-on-a-chip using biopsy-derived organoids. Sci Rep 8:2871

Kiela PR, Ghishan FK (2016) Physiology of intestinal absorption and secretion. Best Pract Res Clin Gastroenterol 30:145-159

Kleiveland CR (2015) Co-cultivation of Caco-2 and HT-29MTX. In: Verhoeckx K et al (eds) The impact of food bioactives on health. Springer, Cham. https://doi.org/10.1007/978-3-319-16104-4_13

König J, Wells J, Patrice D, Cani PD, García-Ródenas CL, MacDonald T, Mercenier A, Whyte J, Freddy Troost F, Brummer R-J (2016) Human intestinal barrier function in health and disease. Clin Transl Gastroenterol 7:e196

Lamers MM, Beumer J, van der Vaart J, Knoops K, Puschhof J, Breugem TI, Ravelli RBG, Jvan Schayck JP, Mykytyn AZ, Duimel HQ, Donselaar E, Riesebosch S, Kuijpers HJH, Schipper D, van de Wetering WJ, de Graaf M, Koopmans M, Cuppen E, Peters PJ, Haagmans BL, Hans CH (2020) SARS-CoV-2 productively infects human gut enterocytes. Science 369:50-54

Lehle AS, Farin HF, Marquardt B, Michels BE, Magg T, Li Y, Liu Y, Ghalandary M, Lammens K, Hollizeck S, Rohlfs M, Hauck F, Conca R, Walz C, Weiss B, Lev A, Simon AJ, Groß O, Gaidt MM, Hornung V, Clevers H, Yazbeck N, Hanna-Wakim R, Shouval DS, Warner N, Somech R, Muise AM, Snapper SB, Bufler P, Koletzko S, Klein C, Kotlarz D (2019) Intestinal inflammation and dysregulated immunity in patients with inherited caspase-8 deficiency. Gastroenterology 156:275-278

Leslie JL, Huang S, Opp JS, Nagy MS, Kobayashi M, Young VB, Spence JR (2015) Persistence and toxin production by Clostridium difficile within human intestinal organoids result in disruption of epithelial paracellular barrier function. Infect Immun 83:138-145

Li AP (2005) Preclinical in vitro screening assays for drug-like properties. Drug Discov Today Technol Actions Summer 2:179-185

Lin J, Hackam DJ (2011) Worms, flies and four-legged friends: the applicability of biological models to the understanding of intestinal inflammatory diseases. Dis Model Mech 4:447-456

Lizuka M, Konno S (2011) Wound healing of intestinal epithelial cells. World J Gastroenterol 7(17):2161-2171

Lozoya-Agullo I, Araujo F, Gonzalez-Alvarez I, Merino-Sanjuan M, Gonzalez-Alvarez M, Bermejo M, Sarmento B (2017) Usefulness of Caco-2/HT29-MTX and Caco-2/HT29-MTX/Raji B coculture models to predict intestinal and colonic permeability compared to Caco-2 monoculture. Mol Pharm 14:1264-1270

Lu W, Rettenmeier E, Paszek M, Yueh MF, Tukey RH, Trottier J, Barbier O, Chen S (2017) Crypt organoid culture as an in vitro model in drug metabolism and cytotoxicity studies. Drug Metab Dispos 45:748754

Mahe MM, Brown NE, Poling HM, Helmrath MA (2017) In vivo model of small intestine. Methods Mol Biol 1597:229-245

Maldonado-Contreras A, Birtley JR, Boll E, Zhao Y, Mumy KL, Toscano J, Ayehunie A, Hans-Reinecker HC, Stern LJ, McCormick BA (2017) Shigella depends on SepA to destabilize the intestinal epithelial integrity via cofilin activation. Gut Microbes 8:544-560

Marrella A, Buratti P, Markus J, Firpo G, Pesenti M, Landry T, Ayehunie S, Scaglione S, Kandarova H, Aiello M (2020) In vitro demonstration of intestinal absorption mechanisms of different sugars using 3D organotypic tissues in a fluidic device. ALTEX 37:255-264
Mathur A, Loskill P, Shao K, Huebsch N, Hong SG, Marcus SG, Marks N, Mandegar M, Conklin BR, Lee LP, Healy KE (2017) Human iPSC-based cardiac microphysiological system for drug screening applications. Sci Rep 5:8883

McCauley HA, Wells JM (2017) Pluripotent stem cell-derived organoids: using principles of developmental biology to grow human tissues in a dish. Development 144:958-962

Ogaki S, Morooka M, Otera K, Kume S (2015) A cost-effective system for differentiation of intestinal epithelium from human induced pluripotent stem cells. Sci Rep 5:17297

Olson H, Betton G, Robinson D, Thomas K, Monro A, Kolaja G, Lilly P, Sanders J, Sipes G, Bracken W, Dorato M, Van Deun K, Smith P, Berger B, Heller A (2000) Concordance of the toxicity of pharmaceuticals in humans and in animals. Regul Toxicol Pharmacol 32: $56-67$

Park J, Wetzel I, Dreau D, Cho H (2018) 3D miniaturization of human organs for drug discovery. Adv Healthcare Mater 7(2)

Peters M, Choy A, Pin C, Leishman D, Moisan A, Ewart L, Guzzie-Peck P, Sura R, Keller D, Scott C, Kolaja K (2020) Developing in vitro assays to transform gastrointestinal safety assessment: potential for microphysiological systems. Lab Chip 20:1177-1190

Peters MF, Landry T, Pin C, Maratea K, Dick C, Wagoner MP, Choy AL, Barthlow H, Snow D, Stevens Z, Armento A, Scott CW, Ayehunie S (2019) Human 3D gastrointestinal microtissue barrier function as a predictor of drug-induced diarrhea. Toxicol Sci 168:3-17

Phalipon A, Sansonetti PJ (2007) Shigella's ways of manipulating the host intestinal innate and adaptive immune system: a toolbox for survival? Immunol Cell Biol 85:119-129

Pizarro TT, Pastorelli L, Bamias G, Garg RR, Reuter BK, Mercado JR, Chieppa M, Arseneau KO, Ley K, Cominelli F (2011) SAMP1/ YitFc mouse strain: a spontaneous model of Crohn's disease like ileitis. Inflamm Bowel Dis 17:2566-2584

Powell AE, Wang Y, Li Y, Poulin EJ, Means AL, Washington MK, Higginbotham JN, Juchheim A, Prasad N, Levy SE, Guo Y, Shyr Y, Aronow BJ, Haigis KM, Franklin JL, Coffey RJ (2012) The panErbB negative regulator Lrig1 is an intestinal stem cell marker that functions as a tumor suppressor. Cell 149(1):146-158

Rousset M, Laburthe M, Pinto M, Chevalier G, Rouyer-Fessard C, Dussaulx E, Trugnan G, Boige N, Brun JL, Zweibaum A (1985) Enterocytic differentiation and glucose utilization in the human colon tumor cell line Caco-2: modulation by forskolin. J Cell Physiol 123:377-385

Sato T, Vries RG, Snippert HJ, van de Wetering M, Barker N, Stange DE, van Es JH, Abo A, Kujala P, Peters PJ, Clevers H (2009) Single LGR5 stem cells build crypt-villus structures in vitro without a mesenchymal niche. Nature 459:262-265

Sawant-Basak A, Rodrigues AD, Lech M, Doyonnas R, Kasaian M, Prasad B, Tsamandouras N (2018) Physiologically relevant, humanized intestinal systems to study metabolism and transport of small molecule therapeutics. Drug Metab Dispos 46:1581-1587

Schiller LR (2009) Diarrhea and malabsorption in the elderly. Gastroenterol Clin N Am 38:481-502

Simon F, Garcia J, Guyot L, Guitton J, Vilchez G, Bardel C, Chenel M, Tod M, Payen L (2019) Impact of interleukin-6 on drugmetabolizing enzymes and transporters in intestinal cells. AAPS J 22:16

Spence JR, Mayhew CN, Rankin SA, Kuhar MF, Vallance JE, Tolle K, Hoskins EE, Kalinichenko VV, Wells SI, Zorn AM, Shroyer NF, Wells JM (2011) Directed differentiation of human pluripotent stem cells into intestinal tissue in vitro. Nature 470(7332):105-109

Srinivasan B, Kolli AR, Esch MB, Abaci HE, Shuler ML, Hickman JJ (2015) TEER measurement techniques for in vitro barrier model systems. J Lab Autom 20(2):107-126

Stevens JL, Baker TK (2009) The future of drug safety testing: expanding the view and narrowing the focus. Drug Discov Today 14:162-167 
Stevens LJ, van Lipzig MMH, Erpelinck SLA, Pronk A, van Gorp J, Wortelboer HM, van de Steeg E (2019) A higher throughput and physiologically relevant two-compartmental human ex vivo intestinal tissue system for studying gastrointestinal processes. Eur J Pharm Sci 137:104989

Sun H, Chow EC, Liu S, Du Y, Pang KS (2008) The Caco-2 cell monolayer: usefulness and limitations. Expert Opin Drug Metab Toxicol 4:395-411

Takenaka T, Harada N, Kuze J, Chiba M, Iwao T, Matsunaga T (2014) Human small intestinal epithelial cells differentiated from adult intestinal stem cells as a novel system for predicting oral drug absorption in humans. Drug Metab Dispos 42:1947-1954

Tavelin S, Taipalensuu J, Söderberg L, Morrison R, Chong S, Artursson P (2003) Prediction of the oral absorption of low permeability drugs using small intestine-like 2/4/A1 cell monolayers. Pharm Res 20: 397-405

Ting H-A, von Moltke J (2019) The immune function of tuft cells at gut mucosal surfaces and beyond. J Immunol 202:1321-1329

Todd K, Tripp R (2019) Human norovirus: experimental models of infection. Viruses 11(2): 151

Vaidyaa B, Shuklab SK, Kollurua S, Huena M, Mullac N, Mehrad N, Kanabarb D, Palakurthid S, Ayehunie S, Muthb A, Gupta V (2019) Nintedanib-cyclodextrin complex to improve bioactivity and intestinal permeability. Carbohydr Polym 204:68-77

van der Flier LG, Clevers H (2009) Stem cells, self-renewal, and differentiation in the intestinal epithelium. Annu Rev Physiol 71:241-260

VanDussen KL, Marinshaw JM, Shaikh N, Miyoshi H, Moon C, Tarr PI, Ciorba MA, Stappenbeck TS (2015) Development of an enhanced human gastrointestinal epithelial culture system to facilitate patientbased assays. Gut 64:911-920

Walter E, Janich S, Roessler BJ, Hilfinger JM, Amidon GL (1996) HT29MTX/Caco-2 cocultures as an in vitro model for the intestinal epithelium: in vitro-in vivo correlation with permeability data from rats and humans. J Pharm Sci 85:1070-1076

Walters E, Wolf E, Whyte J, Mao J, Renner S, Nagashima H et al (2012) Completion of the swine genome will simplify the production of swine as a large animal biomedical model. BMC Med Genom 5:55

Wang B, Kovalchuk A, Li D, Ilnytskyy Y, Kovalchuk I, Kovalchuk O (2020) In search of preventative strategies: novel anti-inflammatory high-CBD cannabis sativa extracts modulate ACE2 expression in COVID-19 gateway tissues. Preprints 2020:2020040315. https:// doi.org/10.20944/preprints202004.0315.v1

Wang Y, Mumm JB, Herbst R, Kolbeck R, Wang Y (2017) IL-22 increases permeability of intestinal epithelial tight junctions by enhancing claudin-2 expression. J Immunol 199:3316-3325

Waterston RH, Lindblad-Toh K, Birney E, Rogers J, Abril JF, Agarwal P, Agarwala R, Ainscough R, Alexandersson M, An P, Antonarakis
SE, Attwood J, Baertsch R, Bailey J, Barlow K, Beck S, Berry E, Birren B, Bloom T, Bork P, Botcherby M, Bray N, Brent MR, Brown DG, Brown SD, Bult C, Burton J, Butler J, Campbell RD, Carninci P, Cawley S, Chiaromonte F, Chinwalla AT, Church DM, Clamp M, Clee C, Collins FS, Cook LL, Copley RR, Coulson A, Couronne O, Cuff J, Curwen V, Cutts T, Daly M, David R, Davies J, Delehaunty KD, Deri J, Dermitzakis ET, Dewey C, Dickens NJ, Diekhans M, Dodge S, Dubchak I, Dunn DM, Eddy SR, Elnitski L, Emes RD, Eswara P, Eyras E, Felsenfeld A, Fewell GA, Flicek P, Foley K, Frankel WN, Fulton LA, Fulton RS, Furey TS, Gage D, Gibbs RA, Glusman G, Gnerre S, Goldman N, Goodstadt L, Grafham D, Graves TA, Green ED, Gregory S, Guigó R, Guyer M, Hardison RC, Haussler D, Hayashizaki Y, Hillier LW, Hinrichs A, Hlavina W, Holzer T, Hsu F, Hua A, Hubbard T, Hunt A, Jackson I, Jaffe DB, Johnson LS, Jones M, Jones TA, Joy A, Kamal M, Karlsson EK, Karolchik D, Kasprzyk A, Kawai J, Keibler E, Kells C, Kent WJ, Kirby A, Kolbe DL, Korf I, Kucherlapati RS, Kulbokas EJ, Kulp D, Landers T, Leger JP, Leonard S, Letunic I, Levine R, Li J, Li M, Lloyd C, Lucas S, Ma B, Maglott DR, Mardis ER, Matthews L, Mauceli E, Mayer JH, McCarthy M, McCombie WR, McLaren S, McLay K, McPherson JD, Meldrim J, Meredith B, Mesirov JP, Miller W, Miner TL, Mongin E, Montgomery KT, Morgan M, Mott R, Mullikin JC, Muzny DM, Nash WE, Nelson JO, Nhan MN, Nicol R, Ning Z, Nusbaum C, O'Connor MJ, Okazaki Y, Oliver K, Overton-Larty E, Pachter L, Parra G, Pepin KH, Peterson J, Pevzner P, Plumb R, Pohl CS, Poliakov A, Ponce TC, Ponting CP, Potter S, Quail M, Reymond A, Roe BA, Roskin KM, Rubin EM, Rust AG, Santos R, Sapojnikov V, Schultz B, Schultz J, Schwartz MS, Schwartz S, Scott C, Seaman S, Searle S, Sharpe T, Sheridan A, Shownkeen R, Sims S, Singer JB, Slater G, Smit A, Smith DR, Spencer B, Stabenau A, Stange-Thomann N, Sugnet C, Suyama M, Tesler G, Thompson J, Torrents D, Trevaskis E, Tromp J, Ucla C, Ureta-Vidal A, Vinson JP, Von Niederhausern AC, Wade CM, Wall M, Weber RJ, Weiss RB, Wendl MC, West AP, Wetterstrand K, Wheeler R, Whelan S, Wierzbowski J, Willey D, Williams S, Wilson RK, Winter E, Worley KC, Wyman D, Yang S, Yang SP, Zdobnov EM, Zody MC, Lander ES (2002) Initial sequencing and comparative analysis of the mouse genome. Nature 420:520-562

Woodcock S, Williamson J, Hassan J, Martin Mackay M (1991) Isolation and characterization of clones from the Caco-2 cell line displaying increased taurocholic acid transport. J Cell Sci 98:323-332

Zang R, Gomez Castro MF, McCune BT, Zeng Q, Rothlauf PW, Sonnek NM, Liu Z, Brulois KF, Wang X, Greenberg HB, Diamond MS, Ciorba MA, Whelan S, Ding S (2020) TMPRSS2 and TMPRSS4 promote SARS-CoV-2 infection of human small intestinal enterocytes. Sci Immunol 5:eabc3582 